\title{
The competitive ability of different millet species on maize under field conditions
}

\author{
György PÁSZTOR - Erzsébet NÁDASY - Rita SZABÓ \\ University of Pannonia, Georgikon Faculty, 8360 Keszthely, Deák F. Str.16; E-mail: pasztor018@gmail.com
}

Keywords: maize, millet, competition, field

\section{Introduction}

Today, maize is one of the most significant grain crops, which occupies the third place after wheat and rice in cultivation. The volume and importance of production lies in the multifaceted utilization.

Plant protection plays a significant role in maize cultivation. Maize is a large row-spacing plant, therefore great attention has to be paid to weed control because its effectiveness is a decisive technological element (Pepó, 2003).

To be able to do this with the right efficiency, knowledge of the influence and interaction of weeds and crops, herbicides, cultivation technology is needed. Among these knowledge, it is also a priority to study and understand the etiology of competition between weed and crop, so the defense against the weed can be carried out easily, thereby preventing the loss of crop yield (Williams and Harvey, 2007). Instead of completely destroying the weeds, the proper regulation of the weed population is desirable to prevent the weed plant from inhibiting the vitality of the crop in physiological development (Hunyadi, 2011).

\section{Materials and methods}

The experiment took place in the summer of 2017. Three millet species (Panicum miliaceum, Panicum ruderale) were sowed on the maize field. The number of millet species changed by parcel, 5, 10, 20 millet per plot. One parcel was 15 square meters. The corn was sown with a machine, and the millet manually, with hands. The number of the millet was set after sprouting. All treatments were repeated three times. Several factors were investigated during the experiment: shoot length and weight, root weight, yield, etc. An evaluation of the shoot lengths is will be described.

\section{Results and discussion}

Based on Figure 1. and 2., significantly longer shoot lengths were measured on the control parcels over the weeks than on the threated parcels. There was not much difference in the first measurement week, but the difference was increasing at later measurement times. In the shoot length test, it was found that both species and all density significantly reduced the shoot length of the maize compared to the control. There was no significant difference between density and species.

\section{Conclusions}

In our experiment, we tested the competition ability of different millet species (Panicum Miliaceum subsp. Miliaceum, Panicum ruderale) based on different parameters in maize. 


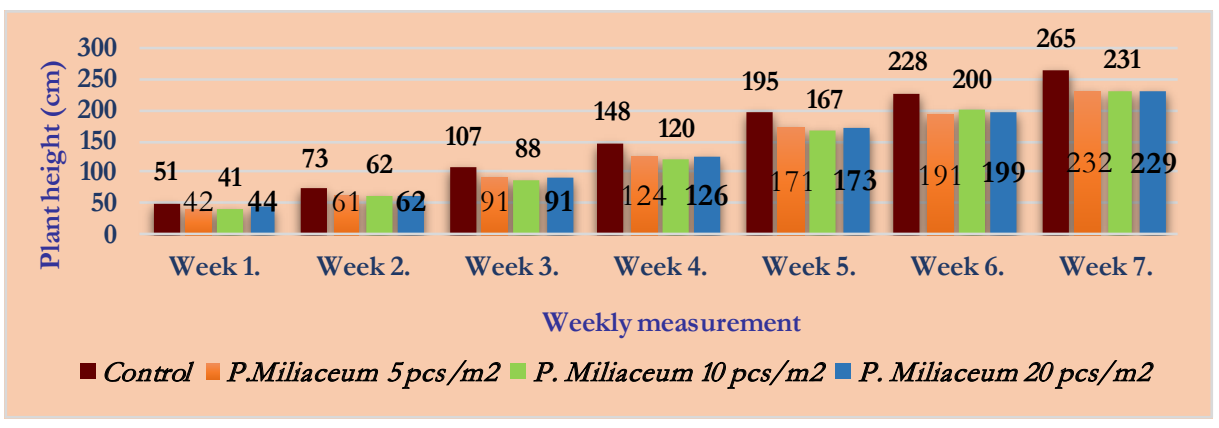

Figure 1: The plant heights of Panicum miliaceum in weekly breakdown

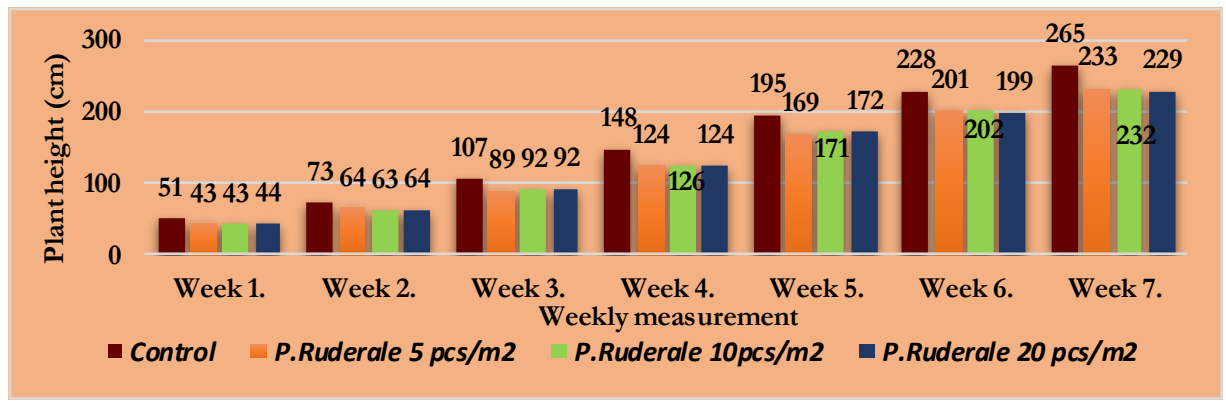

Figure 2: The plant heights of Panicum ruderale in weekly breakdown

In the shoot length assay it was found that both species and density significantly reduced the shoot length of the maize compared to the control. There was no significant difference between single density and sub-species.

The defense strategy should be designed based on the proper application of agrotechnical, mechanical and chemical elements. In the case of infection, plants with narrower stripes (cereals, silage suits, fodder mixes, etc.) should be planted on the field so that they can significantly reduce the growth and seed production of millet.

It is important to note that in addition to these millet species, other species are also spreading, so it is important to carry out important new scientific research for the development of defense.

\section{References}

Hunyadi K.. Béres I., Kazinczi G. (2011): Gyomnövények, gyombiológia, gyomirtás, Mezőgazda kiadó, Budapest. 143-144; 287-308; 519-525.

Pepó P. (2003): Újabb adatok a kukorica hibridspecifikus gyomirtásának fejlesztéséhez, Gyakorlati Agrofórum Extra, 2. szám. 53-54.

Williams, B. J., Harvey, R. G. (2002): Influence of simulated seed rain on the seed bank of wild proso millet. Weed Science 50: 340-343. https://doi.org/10.1614/0043-1745(2002)050[0340:iossro]2.0.co;2 